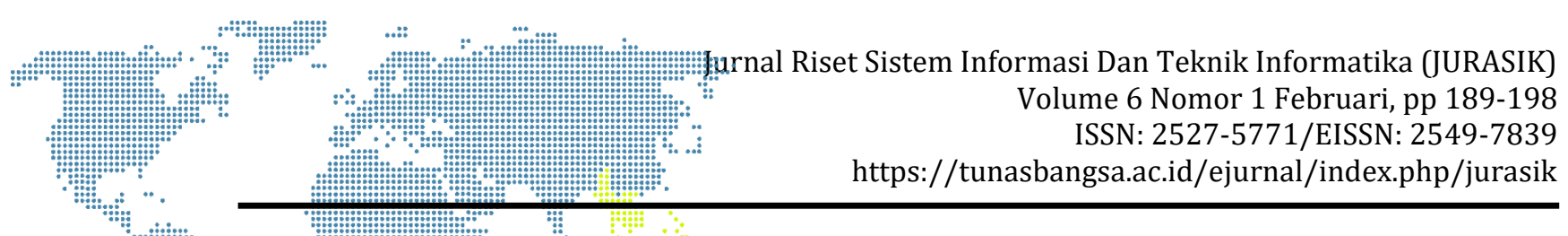

\title{
Algoritma Promethee II Dalam Seleksi Anggota Paskibra Baru Pada SMA Negeri 4 Pematangsiantar
}

\author{
Azi Guntur1' Irfan Sudahri Damanik ${ }^{2}$, M. Fauzan ${ }^{3}$ \\ ${ }^{1}$ Mahasiswa STIKOM Tunas Bangsa, Pematangsiantar, Sumatera Utara, Indonesia \\ 2,3STIKOM Tunas Bangsa, Pematangsiantar, Sumatera Utara, Indonesia \\ Jln. Sudirman Blok A No. 1-3 Pematangsiantar, Sumatera Utara \\ 1azi_guntur@yahoo.co.id, ${ }^{2}$ irfansudahri@stikomtunasbangsa.com, ${ }^{3}$ m.fauzan@stikomtb.ac.id
}

\begin{abstract}
This study aims to conduct selection in determining the members of the New Paskibra in Pematangsiantar Public High School 4 engaged in the field of Education. Besides being based on ability, the addition of several variables and assessment indicators in the form of health variables, height, whether there is togetherness, organizational participation and so on are expected to be able to provide a clearer picture of the criteria of new Paskibra Members in Pematangsiantar 4 Public High School, especially in the best Paskibra Member data which is ambiguous. In this thesis the Promethee II method is a method implemented for determining the criteria for new post-members members and is one of the multi-criteria decision-making methods based on the concept of outranking using pairwise comparisons of alternatives based on each appropriate criterion.
\end{abstract}

Keywords: : Selection of New Pasbira Members, Promethee II

Abstrak

Penelitian ini bertujuan melakukan seleksi dalam menentukan anggota Paskibra Baru di SMA Negeri 4 Pematangsiantar yang bergerak di bidang Pendidikan. Selain berdasarkan kemampuan, penambahan beberapa variabel dan indikator penilaian berupa variabel kesehatan, tinggi badan, ada tidaknya kebersamaan, keikutsertaan organisasi dan lain sebagainya diharapkan mampu dan memberikan gambaran yang lebih jelas terhadap kriteria Anggota Paskibra baru pada SMA Negeri 4 Pematangsiantar terutama pada data Anggota Paskibra terbaik yang bersifat ambigu. Pada skripsi ini metode Promethee II adalah metode yang diimplementasikan untuk penentuan kriteria anggota paskibra baru dan merupakan salah satu metode pengambilan keputusan multikriteria berdasarkan pada konsep outranking dengan menggunakan perbandingan berpasangan dari alternatif-alternatif berdasarkan setiap kriteria yang sesuai.

Kata kunci: Seleksi Anggota Pasbira Baru, Promethee II

\section{PENDAHULUAN}

Pengambilan keputusan merupakan bagian kunci kegiatan dari eksekutif, manajer, karyawan, mahasiswa dan setiap manusia dalam kehidupanya. Masalah yang biasa terjadi dalam pengambilan keputusan adalah informasi tidak cukup, terlampau banyak, tidak akurat, tidak mampu menganalisis masalah dan banyak lagi yang lainnya (Dewi, 2008). Tidak terkecuali dalam hal pengambilan keputusan untuk memilih anggota Paskibra di SMA Negeri 4 Pematangsiantar. Pendidikan mempunyai peranan yang sangat penting, terutama jika dikaitkan dengan upaya peningkatan mutu sumber daya manusia (SDM). Karena hanya dengan sumber daya manusia yang berkualitas dapat meningkatkan martabat manusia itu sendiri (Jamaluddin Sawaji, 2011). Sekolah menengah atas sebagai salah satu bagian penting dalam dunia pendidikan yang ikut bertanggungjawab dalam upaya mencerdaskan kehidupan bangsa mempunyai tanggungjawab dan peran yang 
sangat strategis untuk mengambil bagian dalam mengatasi berbagai masalah pendidikàn terutama kualitas sumber daya manusia.

SMA Negeri 4 Pematang Pematangsiantar dan sangat đi minati oleh para pelajar di dalam kota maupun di luar kota Pematangsiantar, karena sekolah ini terkenal dengan sekolah yg bermutu dan berkualitas menghasilkan siswa - siswa yang cerdas terutama di bidang ekskul, dengan banyaknya ekskul yang ditawarkan akan membuat calon siswa/i memiliki banyak alternatif dalam memilih sebuah ekskul, namun tidak jarang calon siswa/i akan kebingungan dalam menentukan pilihan yang sesuai dengan minat dan kemampuan yang dimiliki salah satunya adalah ekskul Paskibra, masih banyak anggota Paskibra yg masuk tidak sesuai kriteria hal ini di karenakan kurangnya penseleksian anggota paskibra tersebut.

Penelitian tentang menyeleksi anggota Paskibra pernah dilakukan oleh Beberapa peneliti terdahulu yaitu dapat di lihat dalam tabel berikut:

Tabel 1. Peneliti tentang Seleksi Anggota Paskibra

\begin{tabular}{|l|l|l|}
\hline No & \multicolumn{1}{|c|}{ Peneliti Terdahulu } & \multicolumn{1}{|c|}{ Judul } \\
\hline 1 & Rival Sinaga : (2014) & $\begin{array}{l}\text { System Pendukung Keputusan Dalam Menyeleksi } \\
\text { Anggota Paskibraka Dengan Menggunakan Metode } \\
\text { Simple Additive Weighting (SAW) Pada Kantor Dinas } \\
\text { Pemuda Danolahraga Kab.Simalungun" }\end{array}$ \\
\hline 2 & M. Fairuz reza : (2014) & $\begin{array}{l}\text { Sistem Pendukung Keputusan Pemilihan Paskibraka } \\
\text { Pekanbaru Dengan Metode Fuzzy Multi Attribute } \\
\text { Decision Making (FMADM) }\end{array}$ \\
\hline 3 & $\begin{array}{l}\text { Amirul Army Kurrota } \\
\text { A'yuni : (2017) }\end{array}$ & $\begin{array}{l}\text { Sistem Pendukung Keputusan Penerimaan } \\
\text { CalonAnggota Kabupaten } \\
\text { PonorogoMenggunakan Metode ANP Analytic } \\
\text { Network Process) }\end{array}$ \\
\hline
\end{tabular}

Dimana kesimpulan dari penulis adalah analisa sebuah sistem pendukung keputusan yang akan digunakan dalam seleksi anggota paskibra. Perbedaan Dengan penelitian yang penulis lakukan saat ini, terdapat di penggunaan metode dan kriteria.

Berdasarkan permasalahan tersebut, penulis berinisiatif untuk melakukan analisa dan mengembangkan suatu proses pengambilan keputusan, dengan membangun sebuah sistem yang mampu membantu sekolah dalam mengambil keputusan untuk memilih anggota paskibra baru di SMA Negeri 4 Pematangsiantar. Pada proses pengambilan keputusan ini penulis menggunakan metode Promethee II sebagai pencarian bobot dan mengurutkan rekomendasi tertinggi dari hasil yang di peroleh. Dari hasil yang diperoleh, penelitian ini diharapkan dapat menjadi bahan pertimbangan bagi sekolah dalam memilih anggota Paskibra baru SMA Negeri 4 Pematangsiantar. Menambah pengetahuan penulis dalam merancang SPK dengan metode Promethee II (Preference Ranking Organization Method for Enrichment Evaluation II). 


\section{METODOIOOGI PENELITIAN}

\subsection{Penguapulan Data}

Penêlilian dilakukan di Sekólah SMA Negeri 4 Jl. Pattimura No.1, kelurahan Pahlawan, kecamatan Siantar.Timur., Kota Pematang Siantar, Sumatera Utara kode pos 21136Data yang penulis dapatkan dari instansi yang berkaitan dengan penelitian ini berupa data calon seleksi anggota paskibra. Adapun data pendukung seperti terlihat gambar berikut:

Tabel 2. Format Calon Paskibra

\begin{tabular}{|c|c|c|}
\hline No & Nama Siswa & Kelas \\
\hline 1 & Rizky Pauzy Pohan & X IPA 4 \\
\hline 2 & Juan Valentino Purba & X IPA 3 \\
\hline 3 & Paul Hans Damanik & X IPA6 \\
\hline 4 & YoseOskarandaSibarani & X IPA 7 \\
\hline 5 & Jonathan VansigoPasaribu & X IPS 2 \\
\hline 6 & AlfiSarifahMalau & X IPS 1 \\
\hline 7 & Yuni Amalia Nasution & X IPS 1 \\
\hline 8 & Feby Aprilia Napitupulu & X IPA 7 \\
\hline 9 & Widia Levisasaragih & X IPA 1 \\
\hline 10 & Erika Putri Sidabutar & X IPS 3 \\
\hline
\end{tabular}

Kriteria-kriteria penentuan mahasiswa menjadi anggota paskibra pada SMA negeri 4 Pematangsiantar, telah ditetapkan oleh pemimpin paskibra dan anggota lainnya antara lain:

Tabel 3. Tabel Kriteria

\begin{tabular}{|c|c|l|c|}
\hline No & \multicolumn{1}{|c|}{ Kriteria } & Bobot \\
\hline 1 & C1 & Tinggi Badan Laki-laki dan Perempuan (TB) & 20 \\
\hline 2 & C2 & Mahir Baris Berbaris (MB) & 20 \\
\hline 3 & C3 & Sehat Jasmani dan Rohani (SJR) & 15 \\
\hline 4 & C4 & Psikotes (PS) & 15 \\
\hline 5 & C5 & Tidak Cacat Badan (TCB) & 15 \\
\hline 6 & C6 & Nilai Raport (NR) & 15 \\
\hline
\end{tabular}

\subsection{Metode Penelitian}

\section{a) Sistem Pendukung Keputusan}

Sistem Pendukung Keputusan (Decision Support System) pertama kali diungkapkan pada awal tahun 1970-an oleh Michael S. Scott Morton dan didefinisikan sistem pendukung keputusan sebagai sistem berbasis komputer interaktif, yang membantu para pengambil keputusan untuk menggunakan data dan berbagai model untuk memecahkan masalah masalah tidak terstruktur. Sistem ini digunakan untuk membantu pengambilan keputusan dalam situasi yang semiterstruktur dan situasi yang tidak terstruktur, dimana tidak seorang pun tahu secara pasti bagaimana keputusan seharusnya dibuat [1][2]. 


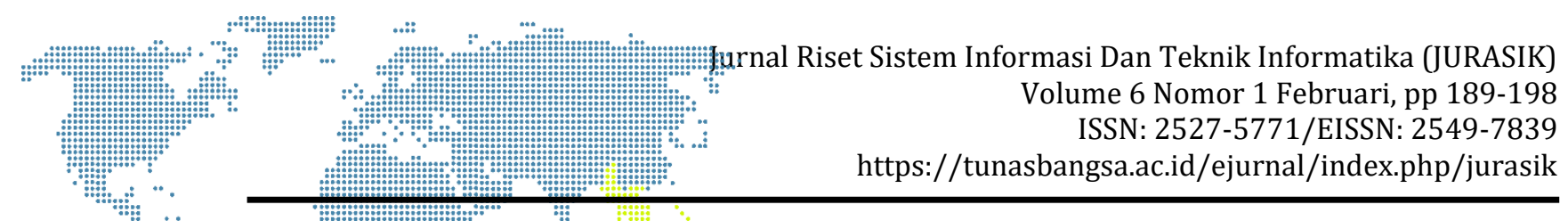

\section{b) Metode Promethee II}

Promethe adalah satu: dari beberapa metode penentuan urutan atau

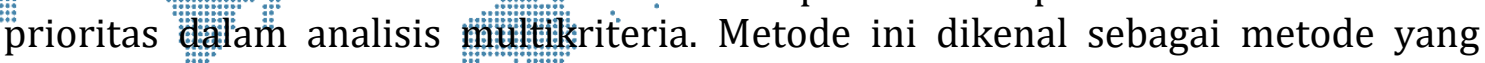
efisien dan simple, tetapi juga yang mudah diterapkan dibanding dengan metode lain untuk menuntaskan masalah multikriteria. Metode ini mampu mengakomodir kriteria pemilihan yang bersifat kuantitatif dan kualitatif. suatu metode penentuan urutan (prioritas) dalam analisis multikriteria. Masalah pokoknya adalah kesederhanaan, kejelasan, dan kestabilan Dugaan dari dominasi kriteria yang digunakan dalam Promethee adalah penggunaan nilai dalam hubungan outranking [3]. Langkah dalam perhitungan metode Promethee II, yaitu[4][5][6]:

1) Menentukan nilai threshold

Untuk menghitung nilai threshold, kita dapat menggunakan rumus veto untuk menentukan nilai $\mathrm{p}$ dan $\mathrm{q}$, berikut rumus veto yang dapat digunakan (Pratama, 2014). Untuk menentukan nilai threshold ditunjukkan pada persaman 1

Preferensi $(p)=v-q$

Dimana:

$\mathrm{v}=$ Threshold veto

$\mathrm{q}=$ indifferen

2) Menentukan tipe fungsi preferensi kriteria

a. Kriteria Biasa (Usual Criterion)

Pada kriteria ini tidak ada perbedaan antara kriteria a dan kriteria b jika $(a)=f(b)$, jika nilai setiap kriteria pada masing-masing alternatif memiliki nilai yang berbeda, maka pembuat keputusan mempunyai preferensi mutlak untuk menentukan alternatif yang memiliki nilai lebih baik. Persamaan 2 menunjukkan kriteria biasa/ tipe I

$H(d)=\left\{\begin{array}{l}0 \text { jika } d \leq 0 \\ 1 \text { jika } d>0\end{array}\right\}$

Keterangan:

$\mathrm{H}(\mathrm{d})=$ fungsi selisih nilai kriteria antar alternatif

$\mathrm{d} \quad=$ selisih nilai kriteria $\{d=(a)-f(b)\}$

b. Kriteria Quasi (Quasi Criterion)

Pada kriteria ini dua alternatif memiliki preferensi yang sama penting selama selisih atau nilai $\mathrm{H}(\mathrm{d})$ dari masing - masing alternatif untuk setiap kriteria tidak melebihi nilai q. Tetapi jika selisih hasil evaluasi untuk masing - masing alternatif melebihi nilai q maka terjadi bentuk preferensi mutlak. Persamaan 3 menunjukkan kriteria quasi/ tipe II

$H(d)=\left\{\begin{array}{l}0 \text { jika } d \leq q \\ 1 \text { jika } d>q\end{array}\right\}$

Keterangan:

(d) = fungsi selisih nilai kriteria antar alternative

$d=$ selisih nilai kriteria $\{d=(a)-f(b)\}$

$q \quad=$ nilai pengaruh signifikan suatu kriteria 


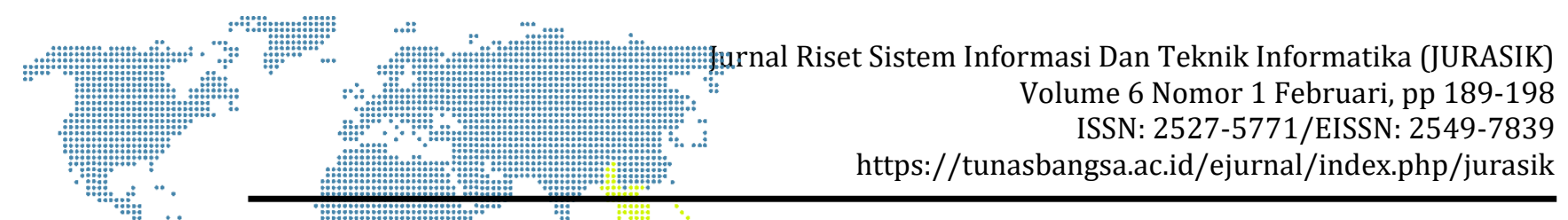

c. Kriterila' Level (Level Criterion)

Nitali indifference threshold (q) dan kecenderungan preferensi preference threshold (p) dapatit ditentủkan secara simultan. Jika d berada diantara nilai $q$ dan $p$ maka dapat diambil kesimpulan bahwa situasi preferensi lemah $((d)=0,5)$. Berikut adalah Persamaan Kriteria Level / tipe IV

$H(d)=\left\{\begin{array}{c}0 \text { jika } d \leq q \\ \frac{1}{2} j i k a q<d \leq p \\ 1 \text { jika } d>q\end{array}\right\}$

Keterangan:

$H(d)=$ fungsi selisih nilai setiap kriteria antar alternatif

$\mathrm{d}=$ selisih nilai kriteria $\{d=(a)-f(b)\}$

$\mathrm{p}=$ nilai atas kecendrungan preferensi

$\mathrm{q} \quad=$ nilai pengaruh signifikan kriteria

3) Perhitungan Nilai Indeks Preferensi Multikriteria

Index preferensi multikriteria ditentukan berdasarkan ketentuan bobot pada masingmasing kriteria dan fungsi preferensi Pi sesuai dengan persamaan 2.8

$\pi_{i j}=\pi\left(a_{i}, a_{j}\right)=\sum_{k=1}^{q} P_{k}\left(a_{i}, a_{j}\right) \cdot W_{i}$

Keterangan:

$P_{k}\left(a_{i}, a_{j}\right) \quad=$ Hasil Perhitungan berdasarkan tipe preferensi

$W_{i} \quad=$ Bobot untuk masing-masing kriteria

4) Perhitungan arah preferensi dipertimbangkan berdasarkan nilai indeks leaving flow $\left(\theta^{+}\right)$, entering flow $\left(\theta^{-}\right)$dan net flow.

a. Leaving Flow

Nilai Leaving Flow didapatkan berdasarkan persamaan 6

$\theta^{+}(a)=\frac{1}{n} \sum n_{x} \in A \varphi(a, x)$

Dimana:

$\varphi(a, x) \quad=$ preferensi nilai $a$ lebih baik daripada nilai $x$

$\mathrm{n} \quad=$ banyaknya jumlah alternatif

$\sum \in A \quad=$ nilai alternative dari tabel preferensi dijumlahkan secara horizontal.

b. Entering Flow

Persamaan 7 menujukkan formula untuk mendapatkan nilai entering flow.

$\theta(a)=\frac{1}{n} \sum x \in A \varphi(x, a)$

Keterangan:

$\varphi(a, x) \quad=$ preferensi nilai $a$ lebih baik daripada nilai $a$

$\mathrm{n} \quad=$ banyaknya jumlah alternatif

$\sum x \in A \quad=$ nilai alternative dari tabel preferensi dijumlahkan secara horizontal.

c. Net Flow

Nilai untuk Net Flow didapatkan dari hasil pengurangan nilai leaving flow dengan nilai entering flow yang dapat dilihat pada persamaan 8

$\theta(a)=\theta^{+}(a)=\theta^{-}(a)$ 


\section{Paskibra}

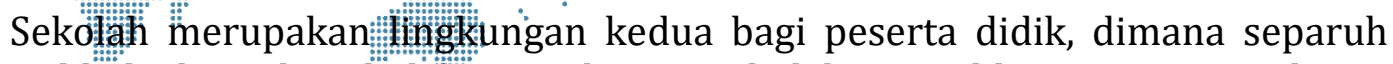
waktu dihabiskan di sekolah. .Untuk itu, sekolah memiliki peran yang besar terhadap perkembangan diri peserta didik. Di sekolah tidak hanya diberikan pelajaran dalam intrakurikuler saja melainkan ada aspek kurikuler dan ekstrakurikuler. Kegiatan ekstrakurikuler Paskibra merupakan suatu kegiatan atau aktivitas di sekolah atau Lembaga pendidikan yang dilaksanakan di luar jam pelajaran yang bertugas sebagai pengibar bendera (Ratnasari \& Suharningsih, 2013)

\section{HASIL DAN PEMBAHASAN}

\subsection{Perhitungan Menggunakan Metode K-means}

Pada tahap ini akan dilakukan pengolahan data menggunakan metode promethee II berdasarkan data penelitian yang diperoleh. Dari data penelitian yang diperoleh selanjutnya data alternatif untuk semua kriteria disederhanakan untuk mempermudah perhitungan seperti gambar berikut:

Tabel 4. Data Alternatif

\begin{tabular}{|c|c|c|c|c|c|c|}
\hline \multirow{2}{*}{ Alternatif } & \multicolumn{7}{|c|}{ Kriteria } \\
\cline { 2 - 7 } & TB & MBB & SJR & PS & TCB & NR \\
\hline A1 & 10 & 6 & 8 & 6 & 8 & 6 \\
\hline A2 & 8 & 8 & 8 & 8 & 6 & 8 \\
\hline A3 & 6 & 6 & 8 & 10 & 8 & 4 \\
\hline A4 & 10 & 10 & 8 & 6 & 6 & 10 \\
\hline A5 & 8 & 8 & 8 & 8 & 8 & 8 \\
\hline A6 & 8 & 8 & 8 & 8 & 8 & 8 \\
\hline A7 & 8 & 10 & 8 & 4 & 10 & 4 \\
\hline A8 & 4 & 6 & 8 & 8 & 8 & 6 \\
\hline A9 & 10 & 8 & 8 & 2 & 8 & 6 \\
\hline A10 & 6 & 8 & 8 & 4 & 8 & 6 \\
\hline
\end{tabular}

Berikut contoh kasus data siswa yang akan dianalisa dengan menggunakan metode Promethee II. Langkah Pertama menormalisasikan matriks keputusan dengan menggunakan persamaan berikut:

$$
\begin{array}{rlrl} 
& R_{i j}=\frac{\left[X_{i j}-\min \left(X_{i j}\right)\right]}{\max \left(X_{i j}\right)-\min \left(X_{i j}\right)} & & \\
\mathrm{C}_{11}=(10-4) /(10-4) & \mathrm{C}_{12}=(8-4) /(10-4) & \mathrm{C}_{13}=(6-4) /(10-4) \\
\mathrm{C}_{11}=6 / 6 & \mathrm{C}_{12}=4 / 6 & \mathrm{C}_{13}=2 / 6 \\
\mathrm{C}_{11}=1 & \mathrm{C}_{12}=0,67 & \mathrm{C}_{13}=0,33
\end{array}
$$

Tabel 5. Hasil Normalisasi Matriks C

\begin{tabular}{|c|c|c|c|c|c|c|}
\hline \multirow{2}{*}{ Normalisasi } & \multicolumn{6}{|c|}{ Kriteria } \\
\cline { 2 - 7 } & C1 & C2 & C3 & C4 & C5 & C6 \\
\hline A1 & 1 & 0 & 0 & 0,5 & 0,5 & 0,33 \\
\hline
\end{tabular}




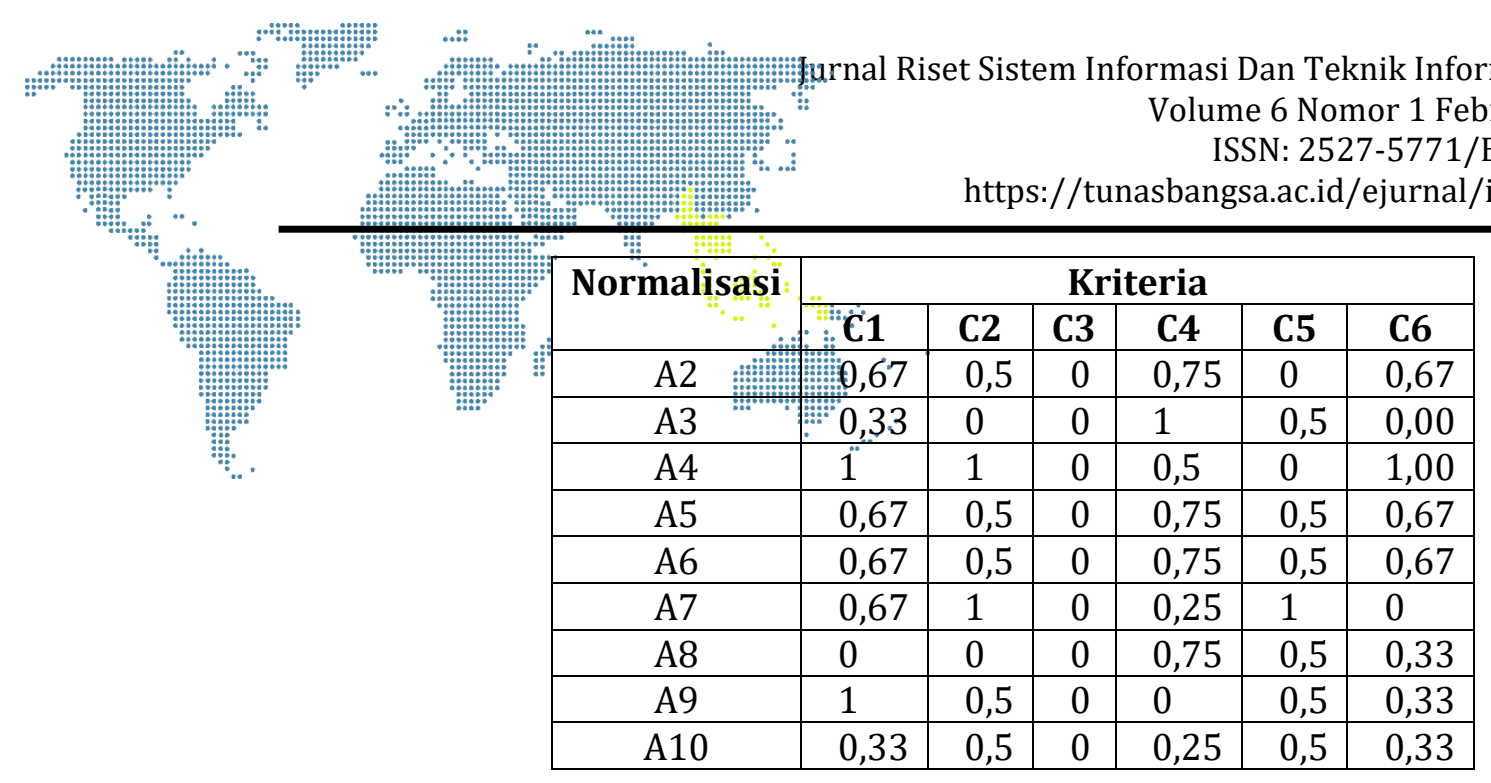

Langkah berikutnya melakukan perhitungan preferensi setiap alternatif dengan menggunakan persamaan berikut :

Tabel 6. Hasil Preferensi Matriks C

\begin{tabular}{|c|l|l|l|l|l|l|}
\hline \multirow{2}{*}{ Alternatif } & \multicolumn{6}{c|}{ Kriteria } \\
\cline { 2 - 7 } & \multicolumn{1}{|c|}{ C1 } & \multicolumn{1}{c|}{ C2 } & \multicolumn{1}{c|}{ C4 } & \multicolumn{1}{c|}{ C5 } & C6 \\
\hline $\mathrm{A} 1, \mathrm{~A} 2$ & 0,33 & 0 & 0 & 0 & 0,5 & 0 \\
\hline $\mathrm{A} 1, \mathrm{~A} 3$ & 0,67 & 0 & 0 & 0 & 0 & 0,33 \\
\hline $\mathrm{A} 1, \mathrm{~A} 4$ & 0 & 0 & 0 & 0 & 0,5 & 0 \\
\hline $\mathrm{A} 1, \mathrm{~A} 5$ & 0,33 & 0 & 0 & 0 & 0 & 0 \\
\hline $\mathrm{A} 1, \mathrm{~A} 6$ & 0,33 & 0 & 0 & 0 & 0 & 0 \\
\hline$\ldots$ & $\ldots$ & $\ldots$ & $\ldots$ & $\ldots$ & $\ldots$ & $\ldots$ \\
\hline$\ldots$ & $\ldots$ & $\ldots$ & $\ldots$ & $\ldots$ & $\ldots$ & $\ldots$ \\
\hline$\ldots$ & $\ldots$ & $\ldots$ & $\ldots$ & $\ldots$ & $\ldots$ & $\ldots$ \\
\hline $\mathrm{A} 10, \mathrm{~A} 7$ & 0 & 0 & 0 & 0 & 0 & 0,33 \\
\hline $\mathrm{A} 10, \mathrm{~A} 8$ & 0,33 & 0,5 & 0 & 0 & 0 & 0 \\
\hline $\mathrm{A} 10, \mathrm{~A} 9$ & 0 & 0 & 0 & 0,25 & 0 & 0 \\
\hline
\end{tabular}

Langkah berikutnya melakukan perhitungan fungsi preferensi agregat dengan menggunakan persamaan sebagai berikut:

Tabel 7. Hasil Preferensi Agregat

\begin{tabular}{cllllllll}
\hline Alternatif & \multicolumn{1}{c}{ C1 } & C2 & C3 & C4 & C5 & C6 & Total \\
\hline A1,A2 & 0,66 & 0 & 0 & 0 & & 0,75 & 0 & 1,41 \\
A1,A3 & 1,34 & 0 & 0 & 0 & 0 & 0,495 & 1,835 \\
A1,A4 & 0 & 0 & 0 & 0 & & 0,75 & 0 & 0,75 \\
A1,A5 & 0,66 & 0 & 0 & 0 & 0 & 0 & 0,66 \\
$\ldots$ & $\ldots$ & $\ldots$ & $\ldots$ & $\ldots$ & $\ldots$ & $\ldots$ & $\ldots$ \\
$\ldots$ & $\ldots$ & $\ldots$ & $\ldots$ & $\ldots$ & $\ldots$ & $\ldots$ & $\ldots$ \\
$\ldots$ & $\ldots$ & $\ldots$ & $\ldots$ & $\ldots$ & $\ldots$ & $\ldots$ & $\ldots$ \\
A10,A7 & 0 & 0 & 0 & 0 & 0 & 0,495 & 0,495 \\
A10,A8 & 0,66 & 1 & 0 & 0 & 0 & 0 & 1,66 \\
A10,A9 & 0 & 0 & 0 & 0,375 & 0 & 0 & 0,375 \\
\hline
\end{tabular}


ilurnal Riset Sistem Informasi Dan Teknik Informatika (JURASIK) Volume 6 Nomor 1 Februari, pp 189-198 ISSN: 2527-5771/EISSN: 2549-7839 https://tunasbangsa.ac.id/ejurnal/index.php/jurasik

Kenmuatan dilakukan perhitungan setiap alternatif dari hasil fungsi preferensi agregat diatas.

Tabel 8. Hasil däî Perhitungan Fungsi Preferensi Agregat

\begin{tabular}{|l|l|l|l|l|l|l|l|l|l|l|}
\hline Alt & \multicolumn{1}{|c|}{$\mathbf{A 1}$} & \multicolumn{1}{|c|}{ A2 } & \multicolumn{1}{|c|}{ A3 } & \multicolumn{1}{|c|}{ 44 } & A5 & \multicolumn{1}{|c|}{ A6 } & A7 & \multicolumn{1}{|c|}{ A8 } & A9 & \multicolumn{1}{|c|}{ A10 } \\
\hline A1 & - & 1,41 & 1,835 & 0,75 & 0,66 & 0,66 & 1,53 & 2 & 0,75 & 1,715 \\
\hline A2 & 1,885 & - & 2,685 & 0,375 & 0 & 0 & 1,755 & 2,85 & 1,635 & 1,94 \\
\hline A3 & 0,75 & 1,125 & - & 0,75 & 0,75 & 0,75 & 1,125 & 1,035 & 1,5 & 1,125 \\
\hline A4 & 3,005 & 2,115 & 4,84 & - & 2,155 & 2,155 & 2,535 & 5,005 & 2,755 & 3,72 \\
\hline A5 & 1,885 & 0,75 & 2,685 & 1,125 & - & 0 & 1,755 & 2,85 & 1,635 & 1,94 \\
\hline A6 & 1,885 & 0,75 & 2,685 & 1,125 & 0 & - & 1,755 & 2,85 & 1,635 & 1,94 \\
\hline A7 & 2,75 & 2,5 & 3,43 & 1,5 & 1,75 & 1,75 & - & 4,09 & 2,125 & 2,43 \\
\hline A8 & 0,87 & 0,75 & 0,495 & 1,125 & 0 & 0 & 1,245 & - & 1,125 & 0,75 \\
\hline A9 & 1 & 1,41 & 2,835 & 0,75 & 0,66 & 0,66 & 1,155 & 3 & - & 1,34 \\
\hline A10 & 1,75 & 0,75 & 1,495 & 0,75 & 0 & 0 & 0,495 & 1,66 & 0,375 & - \\
\hline Total & & & & & & & & & & \\
\hline
\end{tabular}

Langkah berikutnya menentukan arus keluar dan arus outrangking dengan menggunakan persamaan sebagai berikut:

Untuk leaving flow:
A1 $=\frac{1}{10-1} * 11,31=1,257$
A2 $=\frac{1}{10-1} * 13,125=1,458$
A6 $=\frac{1}{10-1} * 14,625=1,625$
A3 $=\frac{1}{10-1} * 8,91=0,99$
A7 $=\frac{1}{10-1} * 22,325=2,481$
A4 $=\frac{1}{10-1} * 28,285=3,143$
A8 $=\frac{1}{10-1} * 6,36=0,707$
A5 $=\frac{1}{10-1} * 14,625=1,625$
A9 $=\frac{1}{10-1} * 12,81=1,423$
$\mathrm{A} 10=\frac{1}{10-1} * 7,275=0,808$
Untuk Entering flow:
A1 $=\frac{1}{10-1} * 15,78=1,753$
A2 $=\frac{1}{10-1} * 11,56=1,284$
A3 $=\frac{1}{10-1} * 22,985=2,554$
A4 $=\frac{1}{10-1} * 8,25=0,917$
A5 $=\frac{1}{10-1} * 5,975=0,664$
A6 $=\frac{1}{10-1} * 5,975=0,664$
A7 $=\frac{1}{10-1} * 13,35=1,483$
A8 $=\frac{1}{10-1} * 25,34=2,816$
A9 $=\frac{1}{10-1} * 13,535=1,504$
$\mathrm{A} 10=\frac{1}{10-1} * 16,9=1,878$

Langkah berikutnya menghitung outranking atau net flow bersih setiap alternatif.
A1 $=1,257-1,753=-0,497$
A6 = 1,625-0,664 = -0,961
$\mathrm{A} 2=1,458-1,284=0,174$
A7 $=2,481-1,483=0,997$
A3 $=0,99-2,554=-1,564$
A8 $=0,707-2,816=-2,109$
$\mathrm{A} 4=3,143-0,917=2,226$
A9 $=1,423-1,504=-0,081$
$\mathrm{A} 5=1,625-0,664=-0,961$
$\mathrm{A} 10=0,808-1,878=1,069$ 


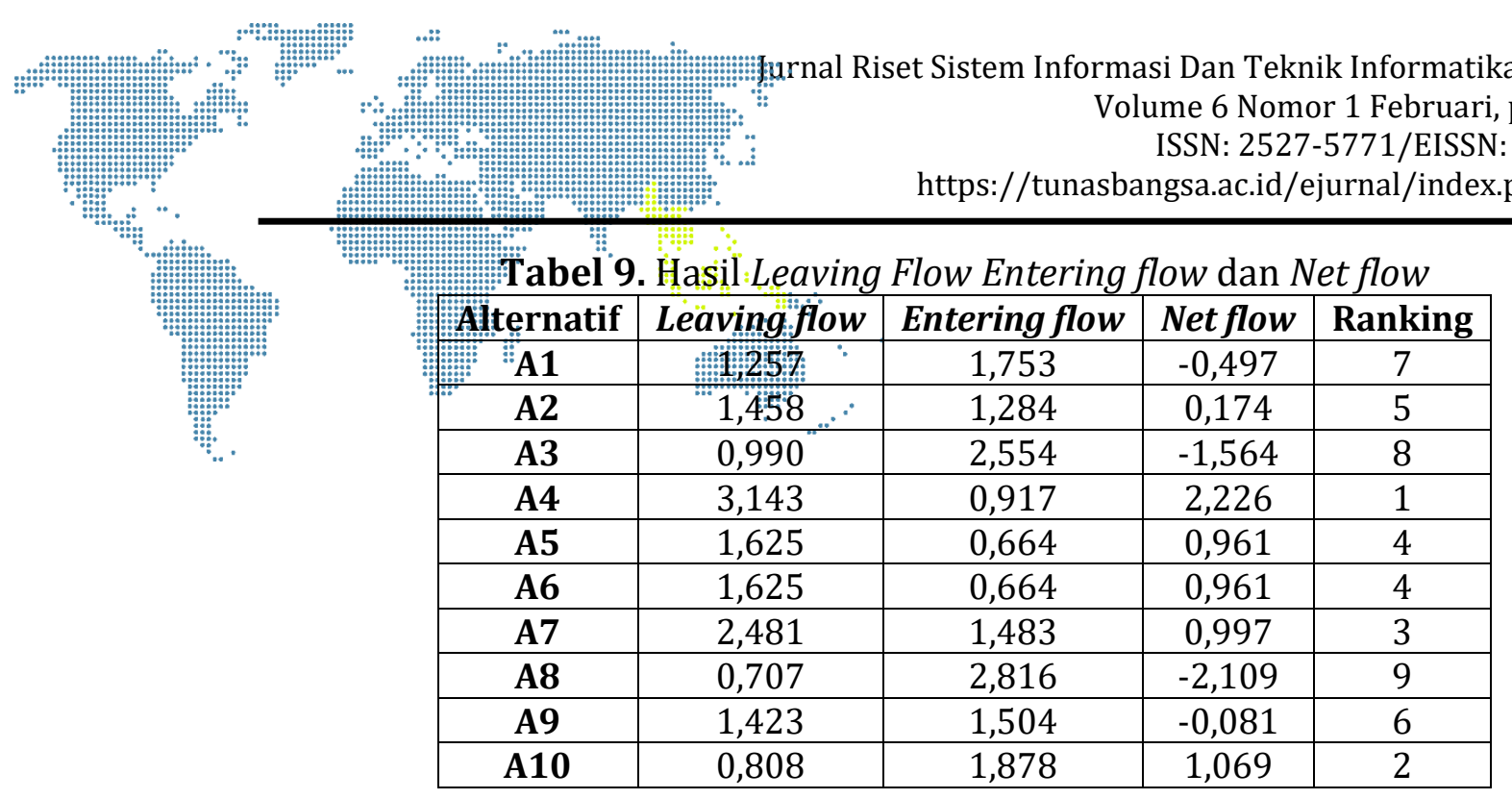

Dari perhitungan alternatif diatas maka A4 (Yose Oskaranda Sibarani), A10 (Erika Putri Sidabutar) dan A7 (Yuli Amalia Nasution) menjadi alternatif paling baik untuk menjadi anggota paskibra.

\begin{tabular}{|c|c|c|c|c|c|}
\hline \multicolumn{6}{|c|}{ Hasil Ranking Berdasarkan PROMETHEE ॥ } \\
\hline \multicolumn{6}{|c|}{ Aternatif dengan nilai Net Flow (NF) paling besar merupakan atternati terbaik. } \\
\hline No. & Kode & Nama Alternotf & NF & Ronk & Keloyakan \\
\hline 1 & 1 & RizkyPauzy Pohan & -0.497 & 7 & Tidak Layak \\
\hline 2 & 2 & Juan Valentino Purba & 0.174 & 5 & layak \\
\hline 3 & 3 & Paul Hans Damanik & -1.564 & 8 & tidak \\
\hline 4 & 4 & Yose Oskaranda Sibarani & 2.226 & 1 & layak \\
\hline 5 & 5 & Jonathan Vansigo Pasaribu & 0.961 & 4 & layak \\
\hline 6 & 6 & Alfi Sarifah Malau & 0.961 & 4 & layak \\
\hline 7 & 7 & Yuni Amalia Nasution & 0.997 & 3 & layak \\
\hline 8 & 8 & Feby Aprilia Napitupulu & -2.109 & 9 & tidak layak \\
\hline \multirow[t]{2}{*}{9} & 9 & Widia Levisa saragih & -0.081 & 6 & tidak layak \\
\hline & 10 & Erika Putri Sidabutar & 1.069 & 2 & layak \\
\hline
\end{tabular}

Gambar 1. Halaman Hasil Perankingan

\section{SIMPULAN}

Berdasarkan hasil dan pembahasan yang didapat maka diambil beberapa kesimpulan sebagai berikut:

a) Salah satu sistem pendukung keputusan yang digunakan yakni dengan menggunakan Metode Promethee II dapat mengurangi tingkat kesalahan (human error) pada pihak panitia penyeleksi paskibra dalam menentukan calon anggota Paskibra pada SMA Negeri 4 Pematangsiantar.

b) Sistem pendukung keputusan dalam menentukan seleksi anggota Paskibra dengan metode Promtehee II dapat mempercepat proses penyeleksian aplikasi dari tiap siswa.

\section{DAFTAR PUSTAKA}

[1] M. S. Rais, "Sistem Pendukung Keputusan Untuk Pemilihan Lokasi Perumahan Menggunakan Analytical Hierarchy Process (Ahp)," J. Ofcomputer Sci., Vol. 2, No. 2, 


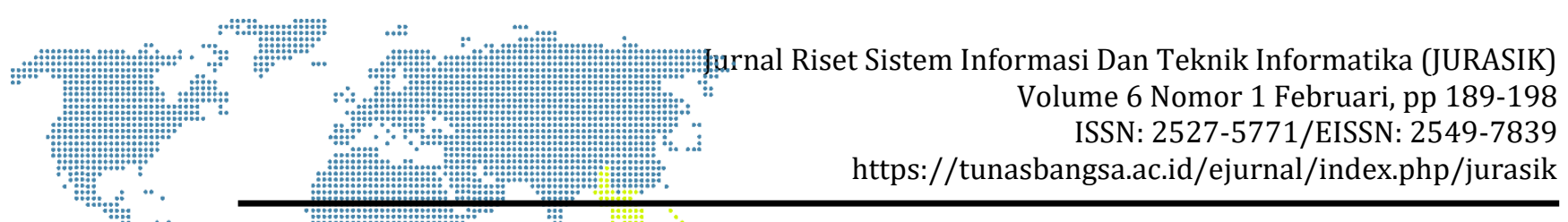

Pp: 59 9 2, 2016.

212] R. A. Sumerdi, R. Taufiq, And"A. A. Permana, "Penerapan Metode Ahp Dalam Sistem Pendumung Keputusañinkenaikan Pangkat Pegawai Di Badan Kepegawaian Dan Pengembagan Sumber Daya Manusia Kota Tangerang," Pros. Sintak, Pp. 522-528, 2018.

[3] M. Wafi, R. S. Perdana, And W. Kurniawan, "Implementasi Metode Promethee Ii Untuk Menentukan Pemenang Tender Proyek ( Studi Kasus: Dinas Perhubungan Dan Llaj Provinsi Jawa Timur )," Vol. 1, No. 11, Pp. 1224-1231, 2017.

[4] T. H. Prasetyo, "Model Promethee Ii Untuk Sistem Pendukung Keputusan Provinsi Sulawesi Barat," Pp. 6-7, 2016.

[5] I. Saputra And M. Ariska, "Penerapan Metode Promethee Ii Pada Sistem Layanan Dan Rujukan Terpadu ( Slrt ) ( Studi Kasus : Dinas Sosial Kabupaten Deli Serdang )," Vol. I, Pp. 276-285, 2017.

[6] N. I. Safitri, "Penerapan Metode Promethee Ii Dalam Pemilihan Masker Wajah Terbaik Untuk Berbagai Jenis Kulit," Sainteks, Pp. 552-558, 2019. 